\title{
Reframing the timeless debate about the legal implications of transsexuality. Special reference to the situation of minors after Spanish Constitutional Court judgment 99/2019 of 18 July 2019
}

OÑATI SOCIO-LEGAL SERIES VOLUME 11, ISSUE 3 (2021), 930-947: INVESTIGATIONS - INVESTIGACIONES - IKERLANAK

DOI LINK: HTTPS://DOI.ORG/10.35295/OSLS.IISL/0000-0000-0000-1187

RECEIVED 05 MAY 2020, ACCEPTED 30 NOVEMBER 2020

\section{ELENA AtIENZA MACÍAS* (iD}

\section{Abstract}

By virtue of the existing laws and regulations in Spain (i.e., Law 3/2007, of 15 March, regulating the register rectification of the entry related to a person's sex) any person of Spanish nationality, of legal age and with sufficient capacity to do so, may request the register rectification for sex change. A new aspect regarding the legal age was introduced not long ago. In this regard, the Constitutional Court of Spain in judgment 99/2019, 18 July 2019, declared unconstitutional article 1.1 of the aforementioned Law 3/2007 since it does not allow the sex change in the registry (and, consequently, the name) to minors, who, however, have sufficient maturity and live in a steady state of transsexuality. The Court states that this prohibition implies a disproportionate interference in minors right to privacy and it is contrary to the principle that guarantees them a space for the free development of his/her identity. Under the pretext of the mentioned landmark case-law we will highlight a series of controversial issues concerning sexual rights. Obviously, this question is still subject to debate and has lost none of its urgency.

\section{Key words}

Transsexuality; transgender minors; sexual rights; right to privacy; human rights

\footnotetext{
This paper is framed within the Postdoctoral Program Juan de la Cierva Formación 2017 from the Ministry of Science, Innovation and Universities. Likewise, the author would like to acknowledge the grant received from the Basque Government (Ref. No. IT1066-16) to support the activities of the Basque University System Research Groups.

* Juan de la Cierva Postdoctoral Research Fellow (Ministry of Science, Innovation and Universities), at the Chair in Law and the Human Genome Research Group, University of the Basque Country UPV/EHU. Email address: elena.atienza@ehu.eus
} 


\section{Resumen}

A tenor de la regulación que, en la actualidad, rige en el Estado español (esto es, la Ley 3/2007, de 15 de marzo, reguladora de la rectificación registral de la mención relativa al sexo de las personas) toda persona de nacionalidad española, mayor de edad y con capacidad suficiente para ello, puede solicitar la rectificación de la mención registral del sexo. Una novedad importante respecto del requisito de mayoría de edad acaecía hace no mucho tiempo. Así las cosas, el Tribunal Constitucional en Sentencia 99/2019 de 18 de julio de 2019, consideraba inconstitucional que el art. 1.1. de la mencionada Ley 3/2007) no permita cambiar el sexo registral (y, consiguientemente, el nombre) a los menores de edad, que, no obstante, tengan "suficiente madurez" y se encuentren en una "situación estable de transexualidad", por entender que dicha prohibición supone una injerencia desproporcionada en su derecho a la intimidad y es contraria al principio que les garantiza un espacio de libertad en la conformación de su identidad. Este singular posicionamiento jurisprudencial nos da pie a abordar en este trabajo una serie de controvertidos conceptos objeto de eterno debate.

\section{Palabras clave}

Transexualidad; menores transexuales; derechos sexuales; derecho a la intimidad; derechos humanos 


\section{Table of contents}

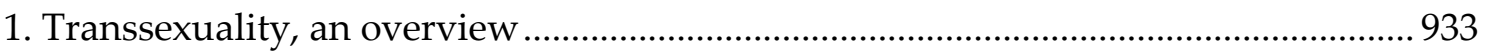

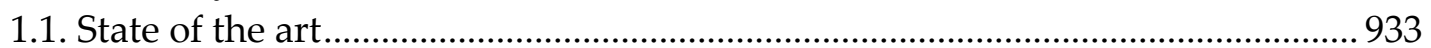

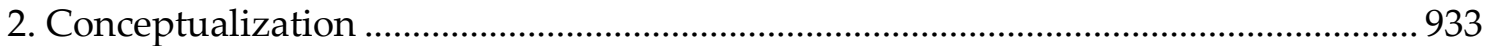

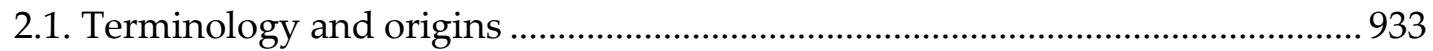

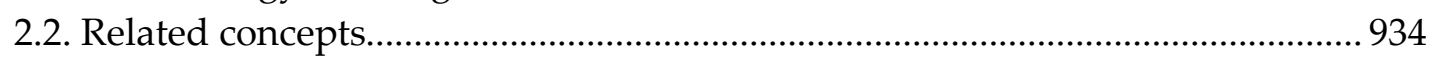

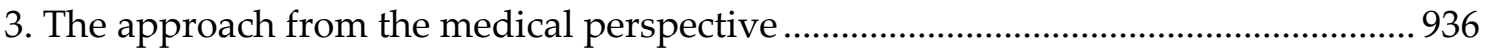

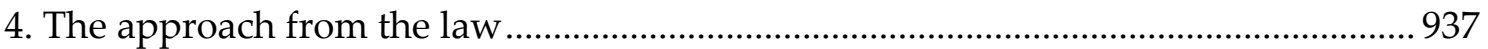

4.1. Case law position: European Court of Human Rights and Spanish Supreme

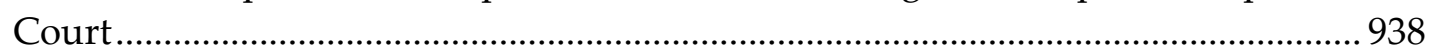

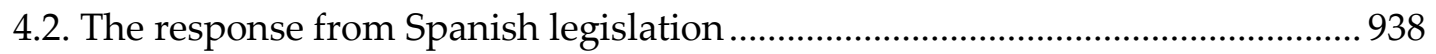

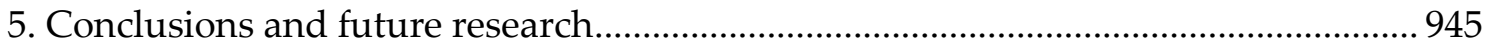

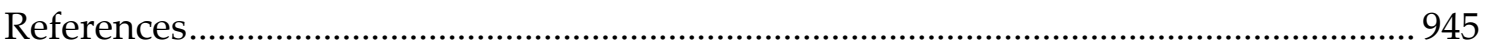

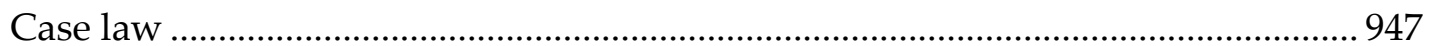




\section{Transsexuality, an overview}

\subsection{State of the art}

The transsexuality study requires an interdisciplinary approach that not only addresses the legal sphere - especially the human rights dimension - but also must be completed with the contribution of other disciplines such as Medicine, Psychology, Sociology, Ethics and Philosophy, without disregarding the fact that it has been subject of intense debates from Politics, with the legal shifts that this issue has been undergoing.

The approval of Law 3/2007, of 15 March, regulating the register rectification of the entry related to a person's sex has been a real milestone, especially the inclusion of this issue within article 10.1 of the Spanish Constitution which proclaims the dignity and free development of the personality - and implicitly the recognition of a controversial "right to sexual identity".

As far as this analysis is concerned, it is noteworthy the suppression of the prerequisite of sexual reassignment surgery as an essential precondition for the registry modification, which had been demanded by case-law (through the Court judgments) (Bustos Moreno 2008).

The most significant aspect of this Law 3/2007 is the fact that it does not require surgical intervention for a name replacement. However, it has the disadvantages that it requires hormonal treatment for two years (with the consequent risk of sterilization) and also that it requires a psychiatric diagnosis, called "gender dysphoria", to be applied. Furthermore, it is an essentially civil law - limited to the area of the Civil Registry which does not respond to all the demands of the groups of people affected, which are currently aiming for a comprehensive or multidisciplinary gender identity Act to regulate transsexuality in all its aspects, including health care. In this regard, some Spanish Autonomous Communities, such as Navarre and the Basque Country, have addressed this last feature and we therefore devote special attention to it in this paper.

\section{Conceptualization}

\subsection{Terminology and origins}

Transsexuality is not strictly speaking a recent reality. What is relatively recent is its surgical treatment as a result of medical progress. Thus, it has existed since ancient times and in different cultures, although it is in our time that it has acquired a pronounced social and scientific entity. The first definition dates from 1953 and was given by $\mathrm{H}$. Benjamin as the irreversible desire to belong to the opposite sex from the genetically established one and to assume the corresponding role and to resort, if necessary, to a hormonal and surgical treatment aimed at correcting this discordance between mind and body (Benjamin 1966).

Moreover, it is important to point out that the terminology used to designate the phenomenon under examination is not uniform and this is reflected in the text of Law 3/2007 itself: on the one hand, the Explanatory Memorandum of this law refers to "transsexuality" and "change of gender identity", on the other hand, Article 4 of itself refers to "diagnosis of gender dysphoria" and "medical treatments to accommodate the 
physical characteristics to those corresponding to the sex claimed" or "sexual reassignment surgery" while the Second Final Provision of the aforementioned Law includes the term "gender dysphoria".

Nevertheless, "transsexuality" is the word we have chosen not only because it is the most widespread word but also because it is precisely the term defended by the transsexual community itself and by psychologists. Accordingly, "transsexualism" is the expression used in the current $10^{\text {th }}$ edition of the International Classification of Diseases (ICD-10, in its acronym) published by the World Health Organization (or WHO), which deals, at the international level, with statistical purposes related to morbidity and mortality. It is a system designed to promote international comparison of the collection, processing, classification and presentation of these statistics and, ultimately, to share and compare health information.

The underlying idea, however, refers to the transgendered person as a person who's sexual or gender identity is contrary to their biological sex, in short, their sexual identity is in conflict with their anatomy. This is the psychosexual syndrome suffered by those who present a discordance between the sex they psychologically feel is their own and the one that corresponds anatomically and in terms of their organs, which leads them to request medical-surgical treatment to remedy this discordance, and to subsequently have their new reality reflected in the Civil Registry.

\subsection{Related concepts}

\subsubsection{Transsexuality and intersex}

Firstly, the differential analysis should be done with intersex. A person is considered intersexual if she or he cannot be unequivocally identified biologically as being female or male on the basis of the existence of chromosomal, hormonal and/or anatomical particularities. In this sense, the individual presents a sexual ambiguity that is usually expressed through the simultaneous presence of female and male sexual organs, that is to say, biological and physiological elements of both sexes concur. This last statement is obviously not a general pattern. In fact, in its classical conception, the "hermaphrodites" (defined below) are what both sexes incorporate integrally. Nevertheless, in intersexuals the coexistence of indices of both sexes varies in each case. This is a chromosomal variation originating during gonadal development in the early prenatal stage, creating insufficient gonadal and genital differentiation (De Montalvo Jääskeläinen 2018, pp. 3238). The intersex condition comes from the concurrence of sex-linked sub-factors that do not align integrally with one of the two sexes (chromosomal, gonadal, internal and external morphological, hormonal, phenotypic and - also - gender assignment and sexual identity).

The term "intersex" is intended to replace older designations, such as hermaphrodite, which may have a discriminatory impact. The word sexuality raises the question of whether it relates to a third sex or whether the person's sex simply has not been or cannot be determined. It differs from hermaphroditism, although sometimes it is used as a synonym since, in its classical conception, hermaphrodites incorporate both sexes integrally. As we have already commented, in intersexual the concurrence of indices of both sexes varies in each case (Lauroba Lacasa 2018, pp. 11-54). 
It also differs from transsexuals since they are individuals who do have an unequivocal biological sex, but feel that they belong psychologically to the other sex, so they often choose to undergo medical interventions to align their bodies with their sexual identity. That is why the condition of transsexual is more complex, since it generates even more social rejection than intersexuality, because it is not possible to resort to merely physiological reasons - as it can be done in intersexuality - that justify this discordance.

As far as the regulation in Spain is concerned, the registration of birth must take place within eight days, in accordance with article 42 of the Law of 8 June 1957 on the Civil Registry. With regard to intersexuals, Article 93.2 of the aforementioned law of 8 June 1957 provides that registration may be rectified by means of a government order (without having to resort to the courts) in the case of erroneous indication of sex when there is no doubt as to the identity of the person born due to other circumstances (in the case, therefore, of registration that does not coincide with the sex assigned afterwards). This assumption has existed since 1957 and was supplemented by "the registration of the sex of persons in cases of gender dysphoria" (i.e., transsexuals), with the reform of Law 3/2007. Therefore, intersex states are considered, in relation to the system of access to the Civil Registry, as original errors, rectifiable by government order. This clarification is valuable in distinguishing between transsexuals and intersexuals: if the transsexuals intend to change their registered sex, the intersexuals intend to correct it (Kuefler 2020, p. 49).

With regard to case law, the Spanish Courts have referred to the difference between transsexuality and intersexuality in the context of the debate on health care coverage under the Public Health System for reassignment operations in intersex states, stating that while transsexualism is characterized by identification with the opposite sex -with the conviction of belonging to it and the desire for morphological sex change-, intersex is a state in which the individual shows sexual characteristics of both sexes, as a result of the configuration of their chromosomes (see the Madrid High Court of Justice Judgement of September 23, 2005 and The Basque Country High Court of Justice Judgement of $21^{\text {st }}$ of June 2005).

\subsubsection{Transsexuality, homosexuality and transvestism}

In parallel to other areas, in the legal sphere there has been a common confusion between sex, gender and sexual orientation. Hence, transsexuality was not legally recognized and was equated with homosexuality. The homosexual person, on the other hand, is well established in his or her gender and there is no doubt about his or her sexual identity. It is precisely because of its decriminalization in 1979 that we can begin to talk about the regulation of issues related to transsexuality independently.

On the other hand, in transvestism, there is no aversion to one's own anatomical sex, with the subject finding in the fetishism of dressing a means of satisfying the libido, but with no doubt as to one's sexual identity.

\subsubsection{Transsexuality and sexual reassignment surgery}

Usually, the concepts of transsexuality and sexual reassignment surgery are also identified, with this medical-surgical treatment being the means used by the transsexual to adapt the anatomical or biological sex that nature has given to the person who is really 
living and feeling, or psychosocial. Therefore, from the medical point of view, sexual reassignment surgery would consist of surgical processes that transsexual women and men carry out in order to, indeed, harmonize their anatomical sex with their sexual identity. It can focus on the genitals - called genital reconstruction or reassignment surgery - and can distinguish operations such as vaginoplasty, metadoioplasty or phalloplasty. There are also feminizing or masculinizing operations of non-genital sexual characteristics, such as a mastectomy or facial surgery.

Moreover, it is important to point out that the first surgery of this type that was made public was performed in Copenhagen on the $3^{\text {rd }}$ of December 1952, on George (later Christine) Jorgensen. A contentious debate was raged over the admissibility or penalization of this medical practice and because of this special attention will be given below.

As a result of all this, in Spain the legislator expressly decriminalized in 1983 this intervention (it would not constitute a crime), subsumed until that date within the crime of injuries (these operations that modified the anatomical sex were framed within the socalled castration). The new Criminal Code - amended by Fundamental Law 1/2015, of 30 March - is in favor of decriminalization by including in its article 156, paragraph 1, the so-called transsexual surgery as one of the cases in which the valid, free, conscious and expressly issued consent of the adult and capable patient exempts the physician from criminal liability in the crime of injury (Atienza Macías and Armaza Armaza 2014, pp. 365-377).

\section{The approach from the medical perspective}

Since 1980, transsexuality has been classified as a mental disorder, and is still listed as such in one of the most comprehensive international disease manuals, the aforementioned $10^{\text {th }}$ edition of the WHO's International Classification of Diseases (ICD10). And with the term "Gender Identity Disorder" it was included, until 2013, in the 4th edition of the Diagnostic and Statistical Manual of Mental Illnesses or DSM-IV-R of the American Psychiatric Association (which has been already repealed after the publication by the American Psychiatric Association of the $5^{\text {th }}$ edition of the Diagnostic and Statistical Manual of Mental Illnesses or DSM-V, which is the edition in force since May 18, 2013).

As a result of this classification, there is a medical diagnosis supported by the dissociation between biological sex and socially attributed gender, known in psychiatry as "gender dysphoria" which broadly refers to the anxiety associated with the conflict between sexual identity and assigned sex. This is reflected in Law 3/2007, which requires precisely a diagnostic report of gender dysphoria as one of its assumptions.

In recent years, a growing number of renowned researchers have advocated the removal of transsexuality from the catalogue of mental illness. Among the reasons given for depathologizing transsexuality it is suggested that this would help to eradicate the stigmatization of transsexuals as "sick". This is an assumption that increases social rejection and generalised transphobia. Likewise, with such a declassification, the current regime of authorisation would be changed, which implies compliance with treatment protocols (such as the aforementioned diagnostic report and medical treatment) to a regime of informed autonomy. 
As a consequence of these social demands, the World Health Organization has published a new edition of its disease manual (ICD-11, adopted on 18 ${ }^{\text {th }}$ June 2018) (Robles García and Ayuso-Mateos 2019, pp. 65-67) that will come into force on the $1^{\text {st }}$ of January 2022 to replace the document in force since 1990 (ICD-10). The new edition of this disease guide replaces the term "transsexualism" with "gender incongruence," defined as a condition related to a person's sexual health rather than a mental or behavioural disorder. Not only the name and status change in the manual (in the chapter on "sexual health-related conditions"), but also the definition. Until now ICD-10 described transsexuality as a desire to live and be accepted as a member of the opposite sex, usually accompanied by discomfort or disagreement with the anatomical sex, and a desire to undergo surgical or hormonal treatment to bring one's body as close as possible to the preferred sex. Now the definition - for adolescence and adulthood - will be related to a pronounced and persistent incongruence between the individual's experience of gender and the sex assigned, often leading to a desire to "transition" to live and be accepted as a person of the experienced gender through hormonal treatment, surgery or other health benefits to align the body as much as desired and as much as possible with the experienced gender. The diagnosis cannot be assigned before the onset of puberty. Behaviour and gender preferences alone are not a basis for assigning the diagnosis.

The modification that has been made is an achievement for the transsexual collective, which is calling for further progress in the total depathologisation of transsexuality. This would imply that it should not be called and defined as "an incongruence", but as an expression of human diversity.

Nonetheless, transsexuality would no longer be classified as a mental disorder in the most wide-ranging international disease manuals: in the WHO International Classification of Diseases (from 2022 with ICD-11) whose new edition replaces the term "transsexualism" with "gender incongruence", defined as a condition related to a person's sexual health, rather than a mental and behavioural disorder and places it in the manual under the chapter on "sexual health conditions" as opposed to its location as a mental disorder (Atienza-Macías 2020). Likewise, transsexuality is excluded in the current Diagnostic and Statistical Manual of Mental Illnesses of the American Psychiatric Association or DSM-V from the list of mental disorders (or "Gender Identity Disorder," as it was called in the previous edition, DSM-IV-R) and is listed under the term "gender dysphoria.

\section{The approach from the law}

The starting point was the European Parliament resolution of 12 September 1989 on discrimination against transsexuals and particularly the recommendation on the status of transsexuals adopted that same year by the Parliamentary Assembly of the Council of Europe, which urged the Committee of Ministers to draw up a document inviting the Member States to legislate on cases of irreversible transsexualism.

As a matter of fact, the legal remedies of the European Union States have been diverse: some states have offered a legal response to transsexuality, other States have moved in the purely administrative field or only in the jurisprudence. Sweden had led the way with the Act of 21 April 1972 on sex determination in established cases. It was followed by Germany with the Act of 10 September 1980 on the change of name and on the 
determination of sexual affiliation in individual cases. Then, Italy with the Act No. 164 of 14 April 1982, "Norme in materia di rettificazione di attribuzione di sesso". The Dutch Act of 24 April 1985. Subsequently, successive laws were published in countries such as Turkey with the Act of 12 May 1988, Denmark with the Act of 1 October 1989 and Norway and its Act of 1 August 1993.

In Spain, the approval of Law 3/2007 of 15 March, regulating the register rectification of the entry related to a person's sex, filled a legal vacuum in which transsexuality was found - which was being saved by means of a somewhat contradictory and fluctuating jurisprudence - eliminating uncertainties and providing a greater degree of legal security.

\subsection{Case law position: European Court of Human Rights and Spanish Supreme} Court

The European Court of Human Rights (ECtHR) has issued significant judgements on this subject. The heart of this aspect is captured in Articles 8, 12 and 14 of the European Convention on Human Rights (ECHR), which refer to the right to respect for private and family life, the right to marry and the prohibition of discrimination, respectively.

In the beginning, though, the general tendency of the ECtHR was little inclined to recognize transsexuality legal consequences. This panorama changed with the landmark judgment of the 25 $5^{\text {th }}$ of March, 1992 (Caselaw Lyne Botella $v$ France), which condemned the French State for not recognising the psychosocial sex of the applicant and considering this refusal to be a violation of Article 8 ECHR. Although it was not until the significant judgments, such as I. $v$ the United Kingdom and Christine Goodwin v the United Kingdom on the same date (i.e. the $11^{\text {th }}$ of July 2002), when a real change in this approach was discussed. In both caselaw notes, the United Kingdom was condemned for violating the right of transsexuals to privacy, to form a family and to marry in accordance with their sexual identity (Articles 8 and 12 of the ECHR), even though the surgery had been carried out.

As a reflection of the jurisprudence emanating from the ECtHR, the Spanish Supreme Court maintained a firm position with respect to demanding sexual reassignment surgery - conditio sine qua non of the change - to access sex change and consequently name change. Among the most significant Supreme Court rulings we can highlight: Spanish Supreme Court Judgment of July 2, 1987; Spanish Supreme Court Judgment of July 15, 1988; Supreme Court Judgment of March 3, 1989 and Supreme Court Judgment of April 19, 1991. This approach, following the approval of Law 3/2007, is revised in a key judgment of the Spanish Supreme Court of 17 September 2007, which, in accordance with that law of 2017, exempts the requirement of sexual reassignment surgery.

\subsection{The response from Spanish legislation}

\subsubsection{State-level regulation}

a) Law 3/2007, of 15 March, regulating the register rectification of the entry related to a person's sex 


\section{Justification and purpose}

The Spanish legal response to transsexuality is based on the fundamental rights recognised in Article 10 of the Spanish Constitution. Indeed, the law itself states that it is a social reality which requires a response from the legislature. Thus, the initial registration of sex and one's name would be changed in order to guarantee the free development of the personality and dignity of persons whose gender identity does not correspond to the sex with they were initially registered. This aspect is crucial. Transsexual groups have long claimed a right to sexual identity and this law seems to recognise, though implicitly, this right to sexual identity or gender identity.

The purpose of Law 3/2007 is to regulate the requirements needed to obtain a change in the registration of a person's sex in the Civil Registry, when that registration does not correspond to his or her true gender identity. It also provides for the change of a person's name in order to not conflict with the sex claimed. Rectification of the sex and change of name are intended to establish as a certain fact the change in gender identity that has already taken place in a manner which will guarantee the legal certainty and the requirements of the general interest. For this purpose, the change of identity must be duly accredited and the registry correction must be carried out in accordance with the regulations on government records of the Civil Registry (thus, article 54 of the Civil Registry Law of 8 June 1957 is amended by this Law).

\section{Conditions for the mention of sex rectification}

1. Diagnosis of gender dysphoria. Fulfilment of this requirement shall be accredited by the opportune medical or clinical psychologist's report.

In this regard, the law does not require that the diagnosis of gender dysphoria be made by two specialists, simultaneously or successively. Nevertheless, the law states the alternative "medical or clinical psychologist" in which it will be referred to:

a. the existence of dissonance between the morphological sex or physiological gender initially registered and the gender identity felt by the applicant or psychosocial sex, as well as the stability and persistence of this dissonance;

b. the absence of personality disorders that could influence, in a decisive way, the existence of the indicated dissonance.

2. Medical treatment for at least two years. Such treatment is aimed at matching the physical characteristics of the subject in question to those corresponding to the sex claimed. Fulfilment of this requirement shall be accredited by a report, preferably by the doctor who directed the treatment or, failing that, by a specialised forensic doctor.

The legal expression "that (the person) has been medically treated" should refer to hormonal treatment. If we have to pay attention to the medical context, this treatment offers a temporary continuity that a surgical intervention lacks. This treatment, according to Law 3/2007, must be dispensed for at least two years to accommodate the physical characteristics of the sex claimed. In this sense, the international scientific community appears to agree that this is a relevant period of time. Thus, the specialists in the field affirm that the first hormonal effects begin to be perceived between the sixth and eighth week, with the changes being completed in approximately six to twenty-four months. 
Article 4.2 of Law 3/2007 is fundamental, which makes it clear that "it shall not be necessary for the granting of the registry correction of the mention of the sex of a person that the medical treatment has included sexual reassignment surgery". The fact that sexual reassignment surgery is not required is one of the most significant aspects of the Spanish law - and a change of approach from the criterion upheld by the Spanish Supreme Court - that responds to one of the historical claims of the transsexual collective.

However, despite the fact that sexual reassignment surgery is not legally required, some transsexuals decide to undergo this type of surgery. In order to do this, they must have a favourable diagnostic report, take some time from the start of the (previous) hormone treatment, be of legal age and have the express and signed petition of the applicant.

In this context of hormone treatment and surgery, is of particular importance the right to information and the adequate provision of the informed consent given for both treatments in writing, in an express and individualised manner. The foregoing was consistent with the provisions of article 8 of Law 41/2002, of 14 November, which is the basic law regulating patient autonomy and rights and obligations in the area of clinical information and documentation.

Furthermore, we should point out that medical treatment is not a necessary requirement when health or age reasons make it impossible to monitor it and medical certification of such circumstances is provided. It should therefore be noted how the Law, in addition to removing the requirement of the courts for sexual reassignment surgery, also allows for an exception to the requirement for physical accommodation treatment (Rubio Torrano 2011, p. 320).

\section{Procedure}

Under the wording of the Law 3/2007 (article 1.1.), any person of Spanish nationality, of legal age and with sufficient capacity to do so, may request the register rectification for sex change.

In this respect it is important to underline an important novelty related to the requirement of the age. By Judgment 99/2019 of 18 July 2019, the Constitutional Court, has declared unconstitutional that the article in question (art. 1.1. of Law 3/2007) does not allow minors (Alventosa Del Río 2016, pp. 153-186) who are "sufficiently mature" and in a "steady state of transsexuality" to change their sex on the register (and, consequently, their name), on the grounds that this prohibition entails a disproportionate interference with their right to privacy and is contrary to the principle that guarantees them an area of freedom in shaping their identity, especially since it is an automatic rule that does not provide for any intermediate regime - for example, a change of name, but not of sex - for situations of transition (Bercovitz Rodríguez-Cano 2020, pp. 307-344, Bustos Moreno 2020).

Above all, we have to understand that, after this Constitutional judgment, minors (those who meet the requirements of Article 4 of Law 3/2007), with "sufficient maturity" and who are in a "steady state of transsexuality", may, on their own (without the need for the assistance of their legal representatives), request a change of sex and the consequent change of name in the register and the fulfilment of these requirements must be assessed on a case-by-case basis. In this sense, on 17 December 2019, the Supreme Court (1 ${ }^{\text {st }}$ 
Plenary Chamber) No. 685/2019 (Rec. No. 1583/2015), following the Constitutional Court's ruling that transsexual minors "with sufficient maturity" can request a change of gender, referred to the Huesca Court the case of a minor who began the legal battle in this area, in order to assess whether the circumstances exist to enable him to carry out his purpose. In the above-mentioned ruling of December 2019, the Civil Division of the Supreme Court applied the doctrine of the Constitutional Court, which considered unconstitutional the provision of the Law 3/2007, of 15 March, regulating the register rectification of the entry related to a person's sex that prevents minors and their parents from requesting a change in the reference to sex in the register (IDIBE 2019). This is the case of "Patrick", a young man of almost 18 years old from Huesca who was born with female sexual organs and was registered as a woman. Five years ago he went to court because of the refusal to allow him to change his gender. With this recent pronouncement, the Supreme Court admits his appeal against the sentence of the Huesca Court and forces this court to listen to the minor to verify if the requirements established by the Constitutional Law to allow him to change his gender are fulfilled, that is, that he has "enough maturity" and that "he is in a stable situation of transsexuality". If this is the case, the Supreme Court indicates that his minority "does not deprive him of the right to request the rectification of the registry mention" and adds that "not having been subjected to treatment for at least two years before the filing of the lawsuit does not prevent him from obtaining the requested rectification". The Court requires the Hearing to hear the minor (in this specific case, Patrick) since, in order to contemplate his maturity and stable situation of transsexuality, the statements that his parents have made in several writings are not sufficient. It also establishes that the processing of the case by the Audiencia should be of a "preferential" nature. After examining the case of the minor (Patrick), the Supreme Court raised, as we announced, a question of the unconstitutionality of the rule that gave rise to the Constitutional Court's ruling (Ruling 685/2019 of 17 December), which is now applied by the high court. In it, the Supreme Court details the case of Patrick, who from the age of three assumed "the generic male role" and was totally adapted to it: "Since he was very young, he stated that he felt like a man and preferred to use a male name. After reviewing the jurisprudence that dates back to the 80 s, the Court explains that "minors are not unaware of the problems of transsexuals". In them - the Court emphasizes - to the problems that are inherent to the stage of childhood and adolescence.

Currently, Law 3/2007, of March 15, allows for the rectification of the mention of sex (and, therefore, name) through a government file, which will be processed at the Civil Registry of the applicant's address. In this regard, the Instruction of 23 October 2018, from the Directorate General of the Registries and Notaries contains guidelines to guide the actions of those responsible for the Civil Registry in relation to applications for name changes for the imposition of one corresponding to the sex different from that resulting from the registration of birth.

There has been a certainly significant change with respect to the previous situation in which the judicial way of the ordinary declarative process for the registry rectification had been consolidated. In this sense, both the General Directorate of Registries and Notaries and the Supreme Court had considered the judicial sentence as the appropriate procedural channel to rectify the registration of the sex of the transsexual. In view of this, 
Law 3/2007 refers to the governmental file route that allows the rectification without the need of a final judicial sentence.

In summary, the work of the legislator is remarkable since it addresses the main claim of the groups directly affected, namely, the legal recognition of register rectification of the entry related to a transsexual's sex and name. Likewise, it is significant that the legislator dispenses with the requirement of sexual reassignment surgery and it is allowed the context of the government record and therefore the promotion of out-ofcourt arrangements.

b) The drafting of a comprehensive law on transsexuality. Special reference to health care coverage

It is important to point out straightaway that Spanish legislator, from the beginning, rejected the legislative option of drafting a comprehensive law on gender identity. Thus, Law $3 / 2007$ is a law that essentially affects civil law issues relating to the rectification of the mention of the sex of persons in the register. In fact, it is not a truly comprehensive law on gender identity.

This Law amends the register mentioning the sex of the person, and through this amendment, a regulation on the identity of the person is introduced. But the identity of the person goes far beyond the mere rectification of the register. A number of issues arising from the recognition of gender identity could have been expressly regulated in this way. Thus, among others, the existence of a right to one's own sexual and gender identity, comprehensive health care for transsexual people, incentives for research in the area of transsexuality, campaigns and actions to combat transphobia, the creation of a legal advice service and psychological and social support for the family and friends of the transsexual person, and the design of a policy of positive discrimination in employment and other legal and social areas. Thus, transsexual associations have been calling for the adoption of an effective comprehensive law on the right to sexual or gender identity that not only covers this aspect of registration rectification but also includes measures in all these areas, with special emphasis on the health field.

With regard to health aspects, it is noteworthy that article 43.1 of the Spanish Constitution recognises the right to health protection. It is understood that health is not only defined as not suffering from illness, but more generically, in the enjoyment of a general, mental and social well-being, which helps to achieve full personal development. In this context, the need for medical treatment of transsexual people must be included. In another case, it would be a paradox, insofar as the groups affected are asking for comprehensive health care (especially that sexual reassignment surgery be included within the National Health System) but on the other hand they are advocating the depathologisation of transsexuality (a common characteristic of transsexuals, as patients, is their refusal to be labeled as sick). Therefore, the most plausible argument would be to situate transsexuality within health in the broadest sense, understood as an aspiration to comprehensive well-being.

In fact, the National Health System does not currently include comprehensive sex reassignment treatment in its health coverage.

In line with the aforementioned Resolution of 12 September 1989 of the European Parliament, which called on the Member States to provide access to comprehensive 
health care for transsexuals, some countries offer this coverage such as the Netherlands, Sweden, Norway and the United Kingdom.

In view of this lack of legislation in Spain, some Autonomous Communities have decided to take over the health protection. In this regard, Andalusia was the Autonomous Community that paved the way, with its parliament approving in February 1999 the provision of health care for transsexuals within the Andalusian Public Health System. We should bear in mind that in the same year, the Ministry of Health of the Andalusian Regional Government created a Gender Identity Disorder Unit at the Carlos Haya University Hospital in Malaga, a centre of reference at the national level since it attends to transsexual patients from other Autonomous Communities. Also, in that year, Madrid and Catalonia began specialized care in mental health and endocrinology, although they would not include interventions and official recognition until 2007 and 2008, respectively. In 2007, the Community of Madrid launched a Multidisciplinary Care Unit for Gender Identity Disorders. In 2008, the Basque Country incorporated genitoplastic surgery.

All in all, this is a complex and widely discussed issue, being one of its major barriers the high cost of clinical treatments for sexual reassignment. Therefore, comprehensive health care in the public sphere is one of the historical demands of the transgender community. Initially, there was a call for its inclusion through a comprehensive gender identity law that would resolve not only civil issues but also social and health policy issues, both in the Draft Law dated in 2000 and in the parliamentary processing of Law $3 / 2007$. Once the idea of a comprehensive gender law was banished, current efforts are focused on the inclusion of that provision in the common services portfolio of the National Health System.

4.2.2. Regulation in the autonomous region. Some emblematic cases: Navarre and the Basque Country

On the one hand, the Foral Community of Navarre - with the Foral Law 12/2009, of November 19, on non-discrimination on the grounds of gender identity and the rights of transsexual people - was a pioneer in dealing with gender identity and transsexuality in a comprehensive manner and from a human rights perspective. Therefore, this law opted for a multidisciplinary regulation that would respond to the health needs - along with the psychological and social needs - of the transsexual collective. For this purpose, it created broad health coverage channelled through the public health system of Navarra, including the training of health care professionals and the publication of a clinical guide, as well as the promotion of research on transsexuality.

There is no question that this law represented a great advance in Navarre, but it proved to be insufficient over the years and in 2017 this law was repealed by a more extensive regulation, Foral Law 8/2017, of 19 June, for the social equality of LGTBI+ people (lesbian, gay, bisexual, transsexual, transgender and intersex people). Its title III, specific to transsexual, transgender and intersex people, is noteworthy, given the lack of rights that they have historically suffered. The law of the province not only recognizes the will of the person to change the legal sex for which he or she is known, for all purposes, but also the intimate need of transsexual persons, when they freely express it, to receive appropriate medical treatment that brings them as close as possible physically to the 
assumed sex. In this sense, comprehensive health care for transsexual persons includes a whole set of procedures defined by psychology and medicine so that transsexual persons can adapt their secondary and primary sexual characteristics, according to each case, to their gender identity, based on the obvious fact that there is a diversity of behaviour and responses among transsexual persons themselves.

This initiative was followed by the Autonomous Community of the Basque Country, which together with Navarre paved the way for the regulation of transsexuality in a specific way. Their regulations, still in force, are Law 14/2012, of 28 June, on nondiscrimination on the basis of gender identity and recognition of the rights of transsexual persons. Following in the footsteps of its predecessor, it provides - as in Navarre - for the creation of a reference unit on transsexuality within the Basque Health Service (namely, Osakidetza) composed of professional staff in the fields of medical care, nursing, psychology, psychotherapy and sexology. At the same time, it includes the creation of a clinical guide for the care of transsexual people, with the objective of articulating sufficient professional consensus in the affected fields. It is worth noting that the Basque Health Service is expected to provide - within the framework of free public health services - the diagnoses, hormonal treatments and also plastic-surgical interventions.

Currently, other autonomous communities such as Andalusia (on the one hand, Law 2/2014 of July 8, comprehensive for the non-discrimination on the basis of gender identity and recognition of the rights of transgender people in Andalusia and, on the other hand, Law 8/2017 of December 28, to guarantee the rights, equal treatment and non-discrimination of LGBT people and their families in Andalusia) and the Community of Madrid (Law 2/2016, of March 29, on Gender Identity and Expression and Social Equality and Non-Discrimination of the Community of Madrid and Law 3/2016, July 22, on comprehensive protection against LGBITphobia and Discrimination for Reasons of Sexual Orientation and Identity in the Madrid Autonomous Region) each have two separate laws, one specific to transgender people and the other to the entire LGTBI+ group.

On the other hand, the Canary Islands (Law 8/2014, of October 28, on non-discrimination on the basis of gender identity and recognition of the rights of transsexual people) and the Valencian Community (Law 8/2017, of April 7, of the Generalitat, comprehensive recognition of the right to gender identity and expression in the Valencian Community) have laws only for transsexual people.

In contrast, Aragon (Law 4/2018, April 19, on Gender Identity and Expression and Social Equality and Non-Discrimination of the Autonomous Community of Aragon), the Balearic Islands (Law 8/2016, May 30, to guarantee the rights of lesbians, gays, trans, bisexuals, and intersex individuals and to eradicate LGBT phobia) Catalonia (Law 11/2014, of October 10, to guarantee the rights of lesbians, gays, bisexuals, transgenders and intersexuals and to eradicate homophobia, biphobia and transphobia), Extremadura (Law 12/2015, of April 8, on social equality for lesbians, gays, bisexuals and transsexuals, transgender and intersex people and public policies against discrimination on the basis of sexual orientation and gender identity in the Autonomous Community of Extremadura), Galicia (Law 2/2014, April 14, for equal treatment and non-discrimination of lesbians, gays, transsexuals, bisexuals and intersex people in Galicia) and Murcia (Law 
8/2016, of 27 May, on social equality for lesbians, gays, bisexuals, transsexuals, transgender and intersex people, and public policies against discrimination on the basis of sexual orientation and gender identity in the Autonomous Community of the Region of Murcia) have passed legislation that jointly refers to the LGTBI+ community.

\section{Conclusions and future research}

This paper has sought to provide an overview of the importance of the historical demands of the transgender community, that is to say, a comprehensive health care coverage within the public health sphere. Initially, there was a call for its inclusion through a comprehensive gender identity law that would resolve not only civil issues but also social and health policy issues, both in the Draft Law dated in 2000 and in the parliamentary processing of Law 3/2007. Therefore, it is necessary to point out that there is a lack of a comprehensive norm on gender identity, which addresses the derived problems in a multidisciplinary manner, similar to what has been done in the autonomous laws, which is applicable to the entire national territory, and which harmonizes and complements the autonomous legislation. ${ }^{1}$ Once the idea of a comprehensive gender law was banished, current efforts are focused on the inclusion of that provision in the common services portfolio of the National Health System. All in all, this is a complex and widely discussed issue, being one of its major barriers the high cost of clinical treatments for sexual reassignment

Likewise, we wonder if the aforementioned Ruling 99/2019 has meant an advance for the inclusion of minors in their exercise of their right to recognition of their gender identity. Although the ruling has allowed minors to carry out this procedure, we consider that the unconstitutionality of Ruling 99/2019 with respect to the requirement of majority is far from being a great advance. This is mainly because, on the one hand, it does not provide any scale or indication to evaluate this sufficient maturity and, on the other hand, it remains in simple jurisprudence and does not carry out any modification in the present law 3/2007 despite declaring it unconstitutional. Related to this, it does not seem very coherent either that the law does not allow to request the change of sex of the minor, but it does allow him/her to start the medical treatment before the age of majority.

\section{References}

Alventosa del Río, J., 2016. Menores transexuales. Su protección jurídica en la Constitución y legislación española. Revista Española de Derecho Constitucional

\footnotetext{
${ }^{1}$ The situation described above would change with the draft of the Law for the Real and Effective Equality of Trans People being debated in March 2021 (with a high degree of controversy) in Spain which - together with contemplating the elimination of the requirements established by the current Law 3/2007 for the change of registered sex of trans people - proposes some basic and common rules in different areas (health, employment, education, justice) for the whole Spanish territory, rules that the autonomous communities, within their competences, should implement, so that the harmonisation demanded would be achieved. The draft law encompasses several medical procedures and rights that refer to this group, both minors and adults. The most important point is the "depathologisation of transsexuality", i.e. to stop considering transsexuality as a disease, in accordance with the policies of the World Health Organisation. The Trans Law also includes medical assistance for sex change processes: hormone treatment, surgeries... It is also important that it provides for bonuses for companies that hire transsexual people, who often face prejudices that make it difficult for them to enter the world of work.
} 
[online], 107, 153-186. Available from: https://doi.org/10.18042/cepc/redc.107.05 [Accessed 17 March 2021].

Atienza Macías, E., and Armaza Armaza, E.J., 2014. La transexualidad: aspectos jurídico-sanitarios en el ordenamiento español. Salud colectiva [online], 10(3), 365377. Available from: https://doi.org/10.18294/sc.2014.399 [Accessed 17 March 2021].

Atienza-Macías, E., 2020. Some Reflections on Transsexuality in the new International Classification of Diseases (ICD 11): A product of The World Health Organization (WHO). Sexuality $\mathcal{E}$ Culture [online], 24(6), 2230-2235. Available from: https://doi.org/10.1007/s12119-020-09721-9 [Accessed 17 March 2021].

Benjamin, H., 1966. The Transsexual Phenomenon. New York: The Julian Press.

Bercovitz Rodríguez-Cano, R., 2020. Transexualidad y menor de edad. Comentario a la STC 99/2019 -Pleno- 18 de julio de 2019 (RTC 2019, 99). Cuadernos Civitas de jurisprudencia civil, 112, 307-344.

Bustos Moreno, Y.B., 2008. La transexualidad (De acuerdo a la Ley 3/2007, de 15 de marzo). Madrid: Dykinson.

Bustos Moreno, Y.B., 2020. La legitimación de los menores de edad a los efectos del reconocimiento legal de su identidad de género. Estado de la cuestión tras la Sentencia del Tribunal Constitucional 99/2019, de 18 de julio de 2019. Derecho Privado y Constitución [online], 36. Available from:

https://doi.org/10.18042/cepc/dpc.36.03 [Accessed 17 March 2021].

De Montalvo Jääskeläinen, F., 2018. Problemas legales en el tratamiento médico de la disforia de género en menores de edad. ADOLESCERE, Revista de Formación Continuada de la Sociedad Española de Medicina de la Adolescencia [online], 4, 32-38. Available from:

https://www.adolescenciasema.org/ficheros/REVISTA\%20ADOLESCERE/vol6nu m2-2018/32-37-

Problemas\%20legales\%20en\%20el\%20tratamiento\%20medico\%20de\%20la\%20disf oria $\% 20 \mathrm{de} \% 20$ genero $\% 20 \mathrm{en} \% 20$ menores $\% 20 \mathrm{de} \% 20 \mathrm{edad} . \mathrm{pdf}$ [Accessed $17 \mathrm{March}$ 2021].

IDIBE, 2019. El TS posibilita el cambio de sexo del menor de edad con suficiente madurez en situación estable de transexualidad. Tribuna, Instituto de Derecho Iberoamericano [online], 27 December. Available from: https://idibe.org/noticiaslegales/ts-posibilita-cambio-sexo-del-menor-edad-suficiente-madurez-situacionestable-transexualidad/ [Accessed 1 May 2020].

Kuefler, M., 2020, Sexualities in Historical Comparative Perspective. In: N.A. Naples, ed., Companion to Sexuality Studies. Oxford: Wiley.

Lauroba Lacasa, E., 2018. Las personas intersexuales y el derecho: Posibles respuestas jurídicas para un colectivo invisible. Derecho privado y Constitución [online], 32, 1154. Available from: https://doi.org/10.18042/cepc/dpc.32.01 [Accessed 17 March 2021]. 
Robles García, R., and Ayuso-Mateos, J.L., 2019. CIE-11 y la despatologización de la condición transgénero. Revista de psiquiatria y salud mental [online], 12(2), 65-67. Available from: https://doi.org/10.1016/j.rpsm.2019.01.002 [Accessed 17 March 2021].

Rubio Torrano, E., 2011. Cambio de sexo (jurídico). In: C.M. Romeo Casabona, ed., Enciclopedia de Bioderecho y Bioética. Granada: Comares, p. 320.

\section{Case law}

Christine Goodwin v the United Kingdom [online]. Application no. 28957/95. European Court of Human Rights Judgment of 11 July 2002. Available from:

http://hudoc.echr.coe.int/eng-press?i=001-60596 [Accessed 17 March 2021].

I $v$ the United Kingdom [online]. Application no. 25680/94. European Court of Human Rights Judgment of 11 July 2002. Available from:

http://www.pfc.org.uk/caselaw/I\%20v\%20United\%20Kingdom.pdf [Accessed 17 March 2021].

Judgment 99/2019, 18 July 2019. Full bench of the Constitutional Court of Spain. State Gazzette [online], 192, 12 August. Available from:

https://www.tribunalconstitucional.es/ResolucionesTraducidas/STC\%20992019.p df [Accessed 17 March 2021].

Sentencia del Tribunal Supremo, Sala de lo Civil № 685/2019, Rec 1583/2015, de 17 de diciembre de 2019 [online]. Available from:

http://www.poderjudicial.es/stfls/TRIBUNAL\%20SUPREMO/DOCUMENTOS\%2 0DE\%20INTER\%C3\%89S/TS\%20Civil\%2017\%20dic\%202019.PDF [Accessed 17 March 2021]. 